\title{
Studies on Chiral Organosulfur Compounds. V. Palladium-Catalyzed Intramolecular Asymmetric Metallo-Ene Reactions via Chiral Allylic Sulfinate-Sulfone Rearrangements
}

\author{
Kunio Hiror* and Kazushige Hirasawa \\ Department of Synthetic Organic Chemistry, Tohoku College of Pharmacy, 4-4-1 Komatsushima, Aoba-ku, Sendai, \\ Miyagi 981, Japan. Received November 15, 1993; accepted December 29, 1993
}

\begin{abstract}
A palladium-catalyzed intramolecular asymmetric metallo-ene reaction was accomplished using a chiral allylic sulfone (prepared by thermal rearrangement of an optically active allylic sulfinate) as an enophile. The stereoselectivity of the reaction was determined by high-performance liquid chromatography with a chiral column. A plausible mechanistic pathway for this asymmetric cyclization is presented.
\end{abstract}

Keywords asymmetric cyclization; metallo-ene reaction; palladium catalyst; sulfinate-sulfone rearrangement; chiral allylic sulfinate; chiral allylic sulfone

Intramolecular asymmetric cycloaddition reactions such as Diels-Alder ${ }^{1)}$ and ene reactions ${ }^{2)}$ can be useful tools for asymmetric synthesis of optically active cyclic compounds. In particular, intramolecular asymmetric ene reactions offer stereoselectivity, ${ }^{3)}$ and our interest has been focussed on asymmetric cyclizations via metallo-ene reactions, ${ }^{4,5)}$ since few asymmetric metallo-ene-type cyclizations have been reported quite recently. ${ }^{6,7)}$ A characteristic of our strategy for asymmetric metallo-ene cyclizations is the use of chiral allylic sulfones as chiral enophiles, since they can be derived from readily available optically active sulfinates by thermal rearrangements. ${ }^{8)}$ A palladiumcatalyzed reaction of a chiral allylic sulfone II, obtained by thermal rearrangement of a chiral allylic sulfinate I, leads initially to the formation of a $\pi$-allylpalladium complex III at the reactive allylic site. The olefin of the allylic sulfone serves as an enophile to undergo a metallo-ene reaction, giving an optically active cyclic compound IV. A new asymmetric carbon center is induced at this cyclization stage owing to the effect of the chirality of the allylic sulfone.

Synthesis of Chiral Allylic Sulfones Regioselective allylic oxidation of nerol tetrahydropyranyl ether (1) with selenium dioxide and tert-butyl hydroperoxide ${ }^{9)}$ was performed in tetrahydrofuran (THF) at room temperature for $5 \mathrm{~h}$ to give 8-hydroxynerol tetrahydropyranyl ether

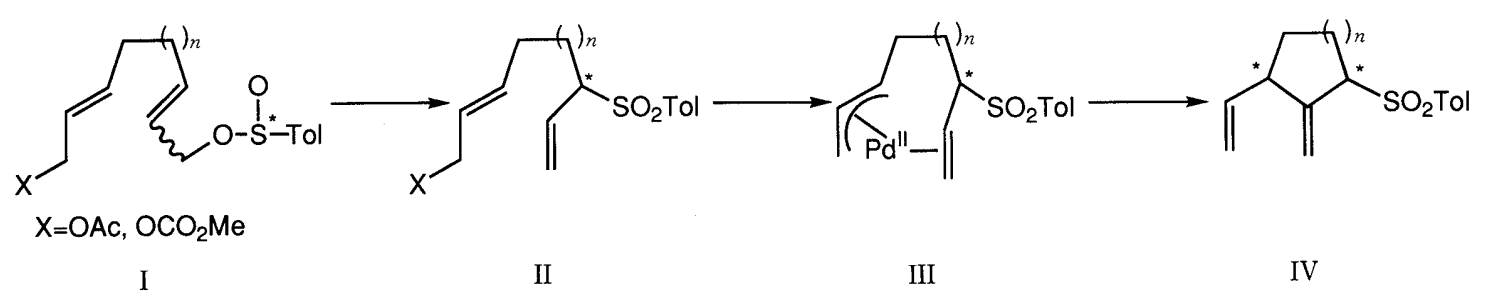

Chart 1

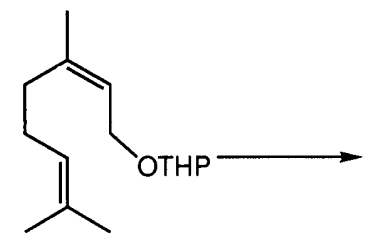

1<smiles>CC(=O)OC/C=C(/C)CCC=C(C)CO</smiles>

5

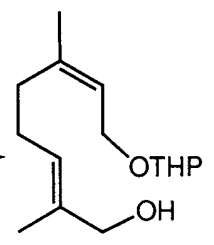

2

6

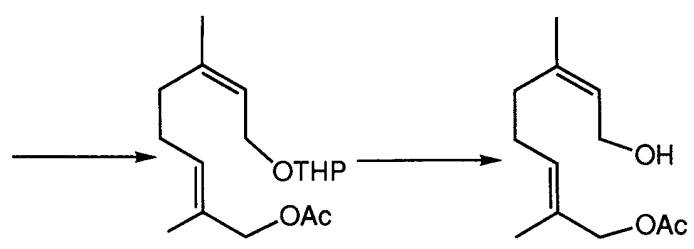

3

4

Chart 2

(C) 1994 Pharmaceutical Society of Japan 


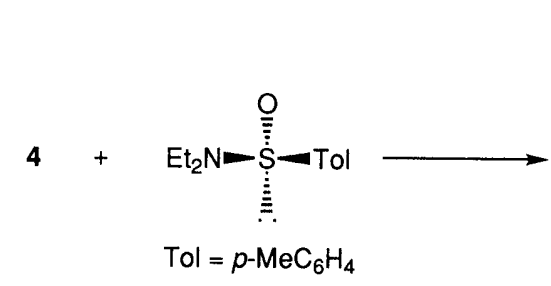

(S) $-(+)-7$

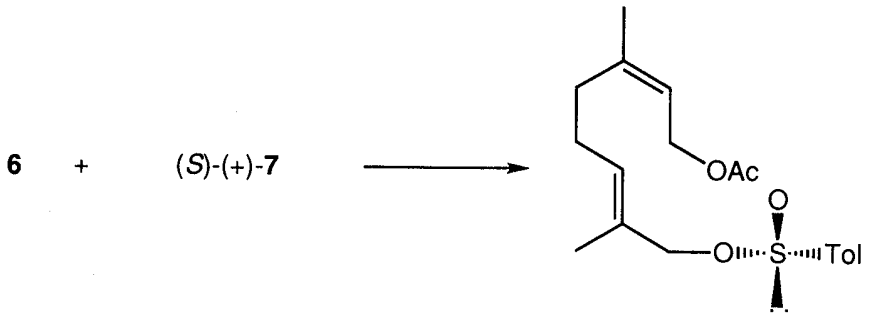

(S) $-(-)-10$

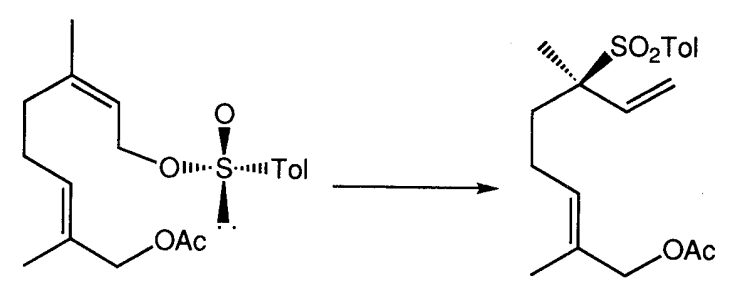

$(R)-(-)-9$

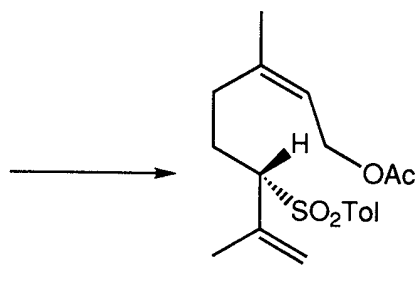

$(S)-(-)-11$

Chart 3

(2) in 55\% yield. Acetylation (90\% yield) of 2 with acetic anhydride-triethylamine-4-dimethylaminopyridine followed by deprotection ( $85 \%$ yield) of the tetrahydropyranyl group in $\mathbf{3}$ with pyridinium $p$-toluenesulfonate in methanol gave 8-acetoxynerol (4). Regioselective allylic oxidation of nerol acetate (5) was carried out in the same way to give 8-hydroxynerol acetate (6) in $51 \%$ yield.

The chiral sulfinylation of the alcohol 4 was accomplished by the alcoholysis of a chiral sulfinamide, $(S)-(+)-$ $N, N$-diethyl- $p$-toluenesulfinamide (7), with 4 in toluene at $0{ }^{\circ} \mathrm{C}$ in the presence of boron trifluoride etherate to give 8-acetoxynerol $(S)-(-)$-p-toluenesulfinate $(8)$ with $96 \%$ stereospecificity in $96 \%$ yield. The sulfinylation of 6 was executed in the same way as described above to give $(S)-(-)-10$ with $83 \%$ stereospecificity in $81 \%$ yield. The absolute configuration and the optical purity of the chiral sulfur atoms in the products $\mathbf{8}$ and $\mathbf{1 0}$ were determined by transformation of the compounds into $(R)-(+)$-phenyl $p$-tolyl sulfoxide of known absolute configuration, ${ }^{10)}$ by the use of phenylmagnesium bromide. The reaction of a sulfinate with a Grignard reagent proceeds with inversion of configuration and complete stereospecificity. ${ }^{10)}$ On the basis of this stereochemical characteristic, the absolute configuration and the enantiomeric excess (ee) of the sulfur atoms in the sulfinates were determined as $(S)-(-)-\mathbf{8}$ $(96 \%$ ee $)$ and $(S)-(-)-10(83 \%$ ee $)$. Thus, the stereospecificity of the alcoholysis of the chiral sulfinamide 7 with $\mathbf{4}$ and $\mathbf{6}$ under the reaction conditions described above was calculated.

Upon heating at $100-105^{\circ} \mathrm{C}$ in $N, N$-dimethylformamide (DMF) for 8-12 h, the chiral sulfinates $(S)-(-)-8$ and $(S)-(-)-10$ (96 and $83 \%$ ee) underwent chiral allylic sulfinate-sulfone rearrangements to give $(R)-(-)-8$-acetoxy-3,7-dimethyl-3-p-toluenesulfonyl-1,6(E)-octadiene (9) and $(S)-(-)-8$-acetoxy-2,6-dimethyl-3-p-toluenesulfonyl-1,6(Z)-octadiene (11) with 40 and $44 \%$ stereospecificity, respectively. The enantiomeric excess of the products was determined on the basis of high-performance liquid chromatography (HPLC) with a chiral column. The
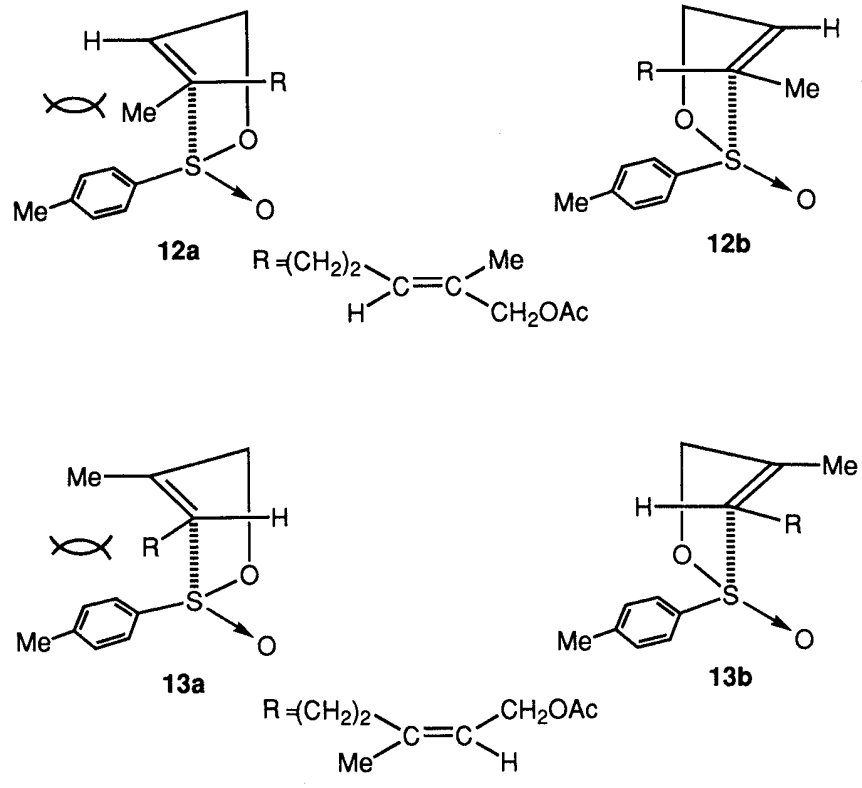

Chart 4

absolute configuration of the products was deduced on the basis of the mechanism of the thermal rearrangements proposed by us previously. ${ }^{8 a}$ Since rather severe steric interaction is observed between the substituents at the $\beta$-positions of the allylic parts and the $p$-tolyl group in 12a and 13a of the five-membered transition states 12 and 13, the rearrangements of $(S)-(-)-8$ and $(S)-(-)-10$ would proceed preferentially via the more stable transition states 12b and 13b, giving $(R)-(-)-9$ and $(S)-(-)-\mathbf{1 1}$, respectively.

Palladium-Catalyzed Metallo-Ene Reactions of Chiral Allylic Sulfones We studied intramolecular asymmetric metallo-ene reactions of the chiral allylic sulfones obtained above. Initially, stereochemical studies on the palladiumcatalyzed intramolecular ene reaction of $( \pm)-9$ were performed using tetrakis(triphenylphosphine)palladium 
TAble I. Studies on Palladium-Catalyzed Intramolecular Ene Reactions of $( \pm)-9^{a}$

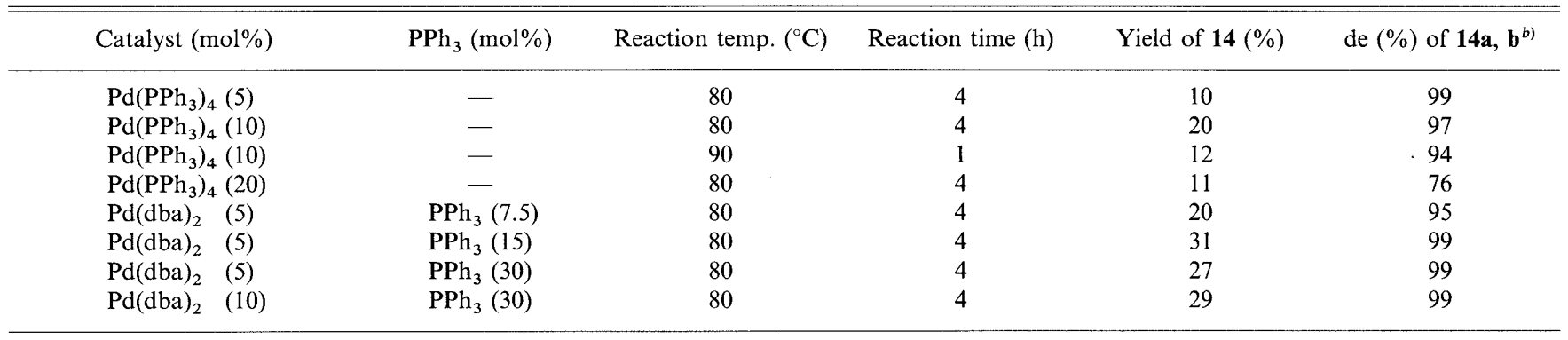

a) Each reaction was carried out in a $0.07 \mathrm{~mol} / 1 \mathrm{AcOH}$ solution of $( \pm)-9$. b) The diastereomeric excess (de) was determined by HPLC analysis.

$\left[\mathrm{Pd}\left(\mathrm{PPh}_{3}\right)_{4}\right]$ or bis(benzylideneacetone)palladium $\left[\mathrm{Pd}(\mathrm{dba})_{2}\right]$ as a catalyst with or without triphenylphosphine $\left(\mathrm{PPh}_{3}\right)$ to examine the chemical yield and diastereoselectivity. The palladium-catalyzed reaction of $( \pm)-9$ in hot acetic acid (AcOH) gave 3-isopiopenyl-1-methyl-2methylene-1-p-toluenesulfonylcyclopentane $(\mathbf{1 4 a}, \mathbf{b})$. The stereochemistry of the diastereomeric product $\mathbf{1 4}$ was determined by NMR spectral analysis. The nuclear Overhauser effect (NOE) was observed between the methyl group at the $\mathrm{C}_{1}$ position and the olefinic hydrogen atom of the isopropenyl group in the NMR spectrum of 14a, whereas no NOE was found in that of $\mathbf{1 4 b}$. The diastereomeric excess was determined by HPLC analysis. The results obtained under various reaction conditions (molar amount of catalyst and ligand, concentration of the reaction solution, and reaction temperature and time) are summarized in Table I.

The reaction of 9 with $20 \mathrm{~mol} \%$ of $\mathrm{Pd}\left(\mathrm{PPh}_{3}\right)_{4}$ in $\mathrm{AcOH}$ at $80^{\circ} \mathrm{C}$ provided lower diastereoselectivity for 14 , whereas the highest diastereoselectivity was obtained with $5 \mathrm{~mol} \%$ of the catalyst. The best molar ratio of $\mathrm{Pd}(\mathrm{dba})_{2}$ to $\mathrm{PPh}_{3}$ for providing high diastereoselectivity was $1: 3$. The palladium-catalyzed cyclization of $(S)-\mathbf{1 1}$ via carbometallation ${ }^{2 d)}$ was examined using $\operatorname{Pd}\left(\mathrm{PPh}_{3}\right)_{4}$ or $\mathrm{Pd}(\mathrm{dba})_{2}$ as a catalyst, but the expected product $15^{2 d)}$ was not formed.

On the basis of the stereochemical results obtained above, the asymmetric palladium-catalyzed ene reaction of $(R)-9(38 \%$ ee) was accomplished under the most favorable reaction conditions found, to give $(1 R, 3 S)$-14a $(19 \%$ ee) as a major product with $50 \%$ stereospecificity and $99 \%$ diastereoselectivity. The diastereomeric excess and the enatiomeric excess of 14 were determined by HPLC analysis with a chiral column. The stereospecificity of this cyclization was calculated on the basis of the enantiomeric excess of the chiral starting allylic sulfone 9 used and the product $(1 R, 3 S)$-14a obtained. The results obtained under several conditions are summarized in Table II.

Stereochemistry of Palladium-Catalyzed Asymmetric Cyclization of the Chiral Allylic Sulfone A palladium catalyst reacted with the chiral allylic sulfone 9 initially at the reactive allylic site (allylic acetate) to form a chiral $\pi$-allylpalladium complex, which underwent an intramolecular metallo-ene reaction via six-membered transition states (16-19) including the palladium catalyst. Since 17a and 19a have extremely severe steric interaction induced by the axially oriented $p$-toluenesulfonyl group, the transition states 16a and 18a with the equatorially oriented $p$-toluenesulfonyl group would be preferred. The
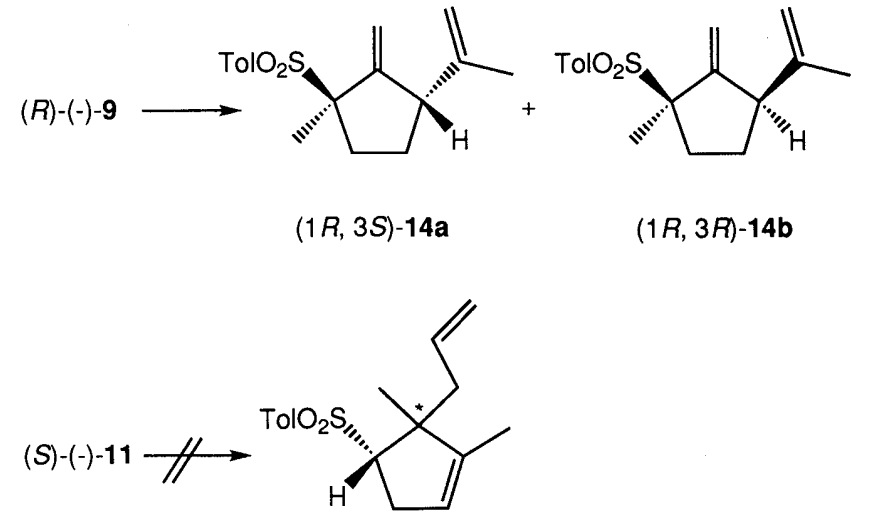

15

Chart 5

TABLE II. Palladium-Catalyzed Metallo-Ene Reactions of $(R)-(-)-9^{a)}$

\begin{tabular}{|c|c|c|}
\hline Catalyst (mol\%) & $\mathrm{PPh}_{3}(\mathrm{~mol} \%)$ & Yield of $14(\%)$ \\
\hline $\operatorname{Pd}(\mathrm{dba})_{2}$ & 15 & 31 \\
\hline $\mathrm{Pd}(\mathrm{dba})_{2} \quad(10)$ & 30 & 29 \\
\hline $\mathrm{Pd}\left(\mathrm{PPh}_{3}\right)_{4}(5)$ & - & 38 \\
\hline $\mathrm{Pd}\left(\mathrm{PPh}_{3}\right)_{4}(10)$ & - & 33 \\
\hline
\end{tabular}

a) The palladium-catalyzed reaction of $(R)-(-)-9(38 \%$ ee $)$ was carried out in AcOH at $80^{\circ} \mathrm{C}$ for $4 \mathrm{~h}$ to give $(1 R, 3 S)$-14a with $19 \%$ ee and $99 \%$ de

metallo-ene cyclization would proceed preferentially via the transition state 16a, which has the conformationally more stable five-six-membered cis fusion, to give $(1 R, 3 S)-14$ a as a major product through the reductive $\beta$-elimination of the palladium catalyst in $\mathbf{1 6 b}$. Compound $(1 R, 3 R)-\mathbf{1 4 b}$ would be formed as a minor product via the less favorable transition state $\mathbf{1 8 a}$, which has the conformationally less stable five-six-membered trans fusion, in the same manner. The ratio of the diastereomers 14a to 14b would be determined on the basis of the stereochemical environment in the transition states 16a and 18a. However, the chirality of the allylic sulfone was slightly lost, not by racemization of the starting allylic sulfone, but presumably by that of the allylic sulfonyl part at the stage of the transition state $\mathbf{1 6 a}$ for the cyclization, because some of the starting allylic sulfone 9 was recovered without any racemization in this palladium-catalyzed reaction. Thus, a chiral allylic sulfone, prepared by a thermal chiral allylic sulfinate-sulfone rearrangement, 

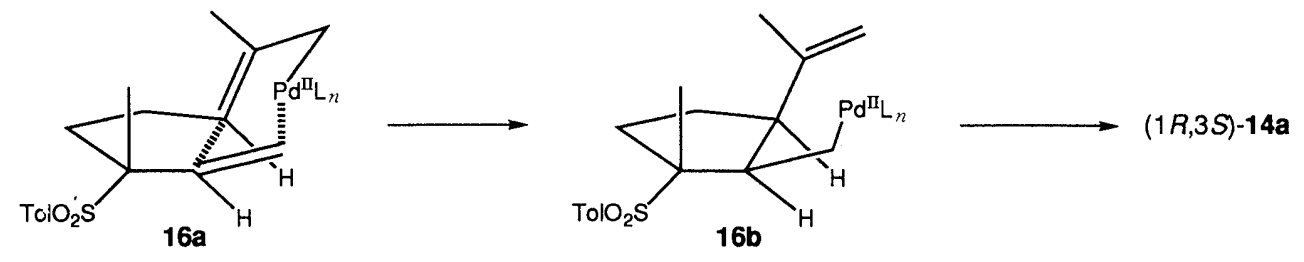

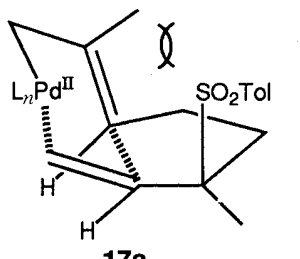

$17 a$

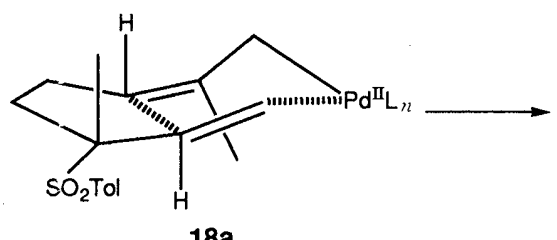

$18 a$

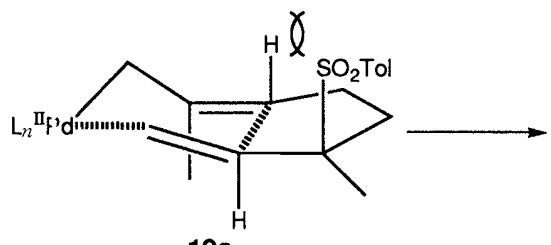

$19 a$
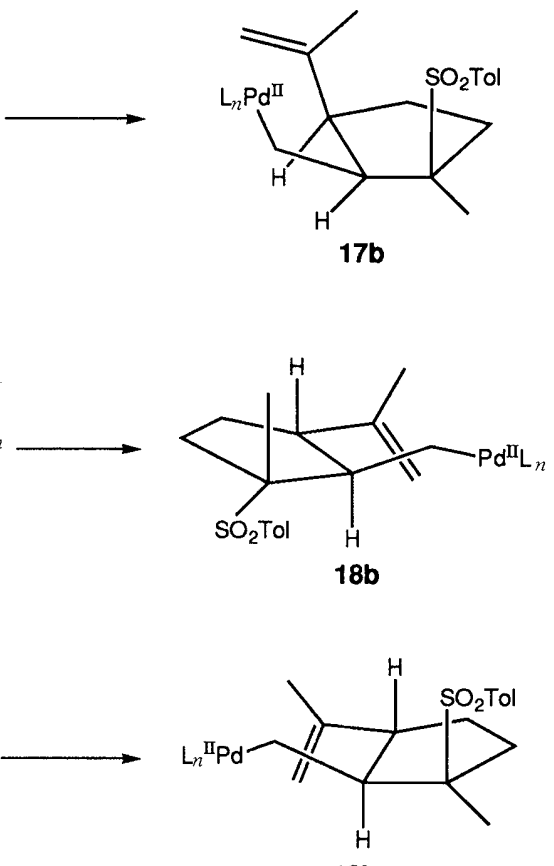

$19 b$

Chart 6

bearing another reactive allylic site at an appropriate position for cyclization underwent an asymmetric metallo-ene reaction, upon treatment with a palladium catalyst in $\mathrm{AcOH}$, to give a chiral cyclopentane derivative with high diastereoselectivity but lower enantiospecificity.

\section{Experimental}

Infrared (IR) spectra were obtained in the indicated state with a JASCO DR-81 Fourier-transform IR spectrometer. NMR spectra were determined in the indicated solvent with a JEOL GSX-400 $\left({ }^{1} \mathrm{H}-\mathrm{NMR}\right.$ $400 \mathrm{MHz}), \mathrm{EX}-270\left({ }^{1} \mathrm{H}-\mathrm{NMR}, 270 \mathrm{MHz}\right)$, or JNM-PMX 60 sI $(60 \mathrm{MHz})$ high-resolution NMR spectrometer; chemical shifts are given in ppm from tetramethylsilane as an internal standard. Splitting patterns are designated as s, singlet; ss, singlet singlet; d, doublet; dd, doublet doublet; m, multiplet. Mass spectra (MS) were taken on a JEOL JMS-DX 303/JMA-DA 5000 system. Optical rotations were measured with a JASCO DIP-360 or 370 polarimeter. HPLC data were obtained with a Tosoh UV-8010, CCPM (column, Tosoh TSK-gel ODS-80TM, Daicel Chiralpak AS). Flash column chromatography was performed with Merck Silica gel $60(230-400 \mathrm{mesh})$. Thin layer or thick layer plates having been dried at $140^{\circ} \mathrm{C}$ for $3.5 \mathrm{~h}$ were used.

2,6-Dimethyl-8-[(tetrahydro-2H-pyran-2-yl)oxy]-2(E),6(Z)-octadien1-ol (2) Selenium dioxide $(93 \mathrm{mg}, 0.84 \mathrm{mmol})$ was added to a solution of 3,7-dimethyl-1-[(tetrahydro-2H-pyran-2-yl)oxy]-2(Z),6-octadiene (1) $(1000 \mathrm{mg}, 4.20 \mathrm{mmol})$ in dichloromethane $(15 \mathrm{ml})$ and $70 \%$ aqueous tert-butyl hydroperoxide $(7.3 \mathrm{ml}, 4.62 \mathrm{mmol})$. The reaction mixture was stirred at room temperature for $3 \mathrm{~h}$ and then concentrated to dryness. The residue was diluted with ether. The organic layer was washed with saturated aqueous $\mathrm{NaCl}$, dried over anhydrous $\mathrm{Na}_{2} \mathrm{SO}_{4}$, and concentrated in vacuo. The residual colorless oil was subjected to column chromatography (ether-hexane, $1: 3$ ) to give 2 (587 $\mathrm{mg}, 55 \%$ yield). IR $v_{\max }^{\mathrm{film}} \mathrm{cm}^{-1}: 3420(\mathrm{OH}), 1650(\mathrm{C}=\mathrm{C}) .{ }^{1} \mathrm{H}-\mathrm{NMR}\left(\mathrm{CDCl}_{3}\right) \delta: 1.16-2.06$ $\left(6 \mathrm{H}, \mathrm{m},\left(\mathrm{CH}_{2}\right)_{3}\right), 1.70\left(3 \mathrm{H}, \mathrm{s}, \mathrm{CH}_{3} \mathrm{C}=\right), 1.80\left(3 \mathrm{H}, \mathrm{s},=\mathrm{C}\left(\mathrm{CH}_{3}\right) \mathrm{CH}_{2} \mathrm{OH}\right)$, $1.50-2.25\left(4 \mathrm{H}, \mathrm{m},\left(\mathrm{CH}_{2}\right)_{2}\right), 3.30-3.90\left(2 \mathrm{H}, \mathrm{m}, \mathrm{CHOCH}_{2}\right), 3.90-4.21$ $\left(3 \mathrm{H}, \mathrm{m}, \mathrm{HO}, \mathrm{THPOCH}{ }_{2}\right), 4.21-4.40(1 \mathrm{H}, \mathrm{m}, \mathrm{OCHO}), 4.40-4.60(2 \mathrm{H}$, $\left.\mathrm{m}, \mathrm{HOCH}_{2}\right), 4.90-5.30(2 \mathrm{H}, \mathrm{m}, 2 \mathrm{C}=\mathrm{CH}) . \mathrm{MS} m / z: 254\left(\mathrm{M}^{+}\right)$. Exact mass determination: 254.1846 (Calcd for $\mathrm{C}_{15} \mathrm{H}_{26} \mathrm{O}_{3}: 254.1882$ ).

1-Acetoxy-2,6-dimethyl-8-[(tetrahydro-2H-pyran-2-yl)oxy]-2(E),6(Z)octadiene (3) A catalytic amount of 4-dimethylaminopyridine was added to a solution of $2(250 \mathrm{mg}, 0.98 \mathrm{mmol})$ and triethylamine $(0.2 \mathrm{ml}$, $1.47 \mathrm{mmol})$ in anhydrous dichloromethane $(8 \mathrm{ml})$. A solution of acetic anhydride $(150 \mathrm{mg}, 1.47 \mathrm{mmol})$ in anhydrous dichloromethane $(3 \mathrm{ml})$ was added to the above solution. The reaction mixture was stirred at room temperature for $1 \mathrm{~h}$. The reaction solution was diluted with dichloromethane, and washed with $10 \%$ aqueous $\mathrm{HCl}$, saturated aqueous $\mathrm{NaHCO}_{3}$ and saturated aqueous $\mathrm{NaCl}$. The organic layers were combined, dried over anhydrous $\mathrm{Na}_{2} \mathrm{SO}_{4}$, and concentrated in vacuo. The residual colorless oil was subjected to column chromatography (ether-hexane, $1: 2$ ) to give $3\left(261 \mathrm{mg}, 90 \%\right.$ yield). IR $v_{\max }^{\text {film }} \mathrm{cm}^{-1}: 1750$ $(\mathrm{C}=\mathrm{O}), 1650(\mathrm{C}=\mathrm{C}) .{ }^{1} \mathrm{H}-\mathrm{NMR}\left(\mathrm{CDCl}_{3}\right) \delta: 1.16-2.06\left(6 \mathrm{H}, \mathrm{m},\left(\mathrm{CH}_{2}\right)_{3}\right)$, $1.70\left(3 \mathrm{H}, \mathrm{s}, \mathrm{CH}_{3} \mathrm{C}=\right), 1.80\left(3 \mathrm{H}, \mathrm{s},=\mathrm{C}\left(\mathrm{CH}_{3}\right) \mathrm{CH}_{2} \mathrm{OH}\right), 1.50-2.25(4 \mathrm{H}$, $\left.\mathrm{m},\left(\mathrm{CH}_{2}\right)_{2}\right), 2.10\left(3 \mathrm{H}, \mathrm{s}, \mathrm{CH}_{3} \mathrm{CO}_{2}\right), 3.30-3.90\left(2 \mathrm{H}, \mathrm{m}, \mathrm{CHOCH}_{2}\right)$, $3.90-4.21\left(2 \mathrm{H}, \mathrm{m}, \mathrm{THPOCH}{ }_{2}\right), 4.21-4.40(1 \mathrm{H}, \mathrm{m}, \mathrm{OCHO}), 4.50(2 \mathrm{H}$, $\left.\mathrm{s}, \mathrm{AcOCH}_{2}\right), 4.90-5.40(2 \mathrm{H}, \mathrm{m}, 2 \mathrm{C}=\mathrm{CH})$. MS m/z: $296\left(\mathrm{M}^{+}\right)$. Exact mass determination: 296.1717 (Calcd for $\mathrm{C}_{17} \mathrm{H}_{28} \mathrm{O}_{5}: 296.1988$ ).

8-Acetoxy-3,7-dimethyl-2( $Z), 6(E)$-octadien-1-ol (4) Pyridinium $p$ toluenesulfonate $(8.5 \mathrm{mg}, 0.034 \mathrm{mmol})$ was added to a solution of 3 ( $200 \mathrm{mg}, 0.68 \mathrm{mmol})$ in methanol $(2 \mathrm{ml})$. The reaction mixture was stirred at room temperature for $12 \mathrm{~h}$ and then concentrated to dryness. The residue was diluted with ether. The solution was washed with saturated aqueous $\mathrm{NaCl}$. The organic layers were combined, dried over anhydrous $\mathrm{Na}_{2} \mathrm{SO}_{4}$, and concentrated in vacuo. The residual colorless oil was subjected to column chromatography (ether-hexane, $1: 1$ ) to give 4 (123 mg, 85\% yield). IR $v_{\max }^{\text {film }} \mathrm{cm}^{-1}: 3400(\mathrm{OH}), 1750(\mathrm{C}=\mathrm{O}), 1650$ 
$(\mathrm{C}=\mathrm{C}) .{ }^{1} \mathrm{H}-\mathrm{NMR}\left(\mathrm{CDCl}_{3}\right) \delta: 1.70\left(3 \mathrm{H}, \mathrm{s}, \mathrm{CH}_{3} \mathrm{C}=\right), 1.80(3 \mathrm{H}, \mathrm{s}$, $\left.\mathrm{C}_{3} \mathrm{C}_{3}\left(\mathrm{CH}_{2}\right)=\mathrm{CHOH}\right), 1.50-2.25\left(4 \mathrm{H}, \mathrm{m},\left(\mathrm{CH}_{2}\right)_{2}\right), 2.10(3 \mathrm{H}, \mathrm{s}$, $\left.\mathrm{CH}_{3} \mathrm{CO}_{2}\right), 3.45-4.20\left(3 \mathrm{H}, \mathrm{m}, \mathrm{HOCH}_{2}\right), 4.45\left(2 \mathrm{H}, \mathrm{s}, \mathrm{AcOCH}_{2}\right)$, 5.15-5.50 $(2 \mathrm{H}, \mathrm{m}, 2 \mathrm{C}=\mathrm{CH})$. MS $\mathrm{m} / z: 212\left(\mathrm{M}^{+}\right)$. Exact mass determination: 212.1507 (Calcd for $\mathrm{C}_{12} \mathrm{H}_{20} \mathrm{O}_{3}: 212.1012$ ).

8-Acetoxy-2,6-dimethyl-2(E),6(Z)-octadien-1-ol (6) Selenium dioxide $(57 \mathrm{mg}, 0.51 \mathrm{mmol})$ was added to a solution of 1-acetoxy-3,7-dimethyl$2(Z), 6$-octadiene $(5)(1000 \mathrm{mg}, 5.10 \mathrm{mmol})$ in dichloromethane $(18 \mathrm{ml})$ and $70 \%$ aqueous tert-butyl hydroperoxide $(8.9 \mathrm{ml}, 5.61 \mathrm{mmol})$. The reaction mixture was stirred at room temperature for $3 \mathrm{~h}$ and then concentrated to dryness. The residue was diluted with ether. The organic layer was washed with saturated aqueous $\mathrm{NaCl}$, dried over anhydrous $\mathrm{Na}_{2} \mathrm{SO}_{4}$, and concentrated in vacuo. The residual colorless oil was subjected to column chromatography (ether-hexane, 1:3) to give 6 (554 mg, $51 \%$ yield). 6: IR $v_{\max }^{\text {film }} \mathrm{cm}^{-1}: 3420(\mathrm{OH}), 1740(\mathrm{C}=\mathrm{O}), 1670$ $(\mathrm{C}=\mathrm{C}) .{ }^{1} \mathrm{H}-\mathrm{NMR}\left(\mathrm{CDCl}_{3}\right) \delta: 1.50-1.85\left(6 \mathrm{H}, \mathrm{m}, 2 \mathrm{CH}_{3} \mathrm{C}=\right), 2.00(3 \mathrm{H}$, s, $\left.\mathrm{CH}_{3} \mathrm{CO}_{2}\right), 2.05-2.35\left(4 \mathrm{H}, \mathrm{m},\left(\mathrm{CH}_{2}\right)_{2}\right), 3.85\left(2 \mathrm{H}, \mathrm{s}, \mathrm{HOCH}_{2}\right), 4.95$ $\left(2 \mathrm{H}, \mathrm{d}, J=7 \mathrm{~Hz}, \mathrm{CH}_{2} \mathrm{OAc}\right), 5.05-5.50(2 \mathrm{H}, \mathrm{m}, 2 \mathrm{C}=\mathrm{CH}) . \mathrm{MS} m / z: 212$ $\left(\mathrm{M}^{+}\right)$. Exact mass determination: 212.1295 (Calcd for $\mathrm{C}_{12} \mathrm{H}_{20} \mathrm{O}_{3}$ : 212.1412).

8-Acetoxy-3,7-dimethyl-2 $(Z), 6(E)$-octadienyl $(S)$ - $(-)$-p-Toluenesulfinate (8) A mixture of $(S)-(+)-N, N$-diethyl- $p$-toluenesulfinamide (7) $(99.6 \mathrm{mg}, 0.47 \mathrm{mmol}, 100 \% \mathrm{ee})$ and $4(200 \mathrm{mg}, 0.94 \mathrm{mmol})$ in anhydrous toluene $(10 \mathrm{ml})$ was stirred at $0^{\circ} \mathrm{C}$ for $3 \mathrm{~h}$ in the presence of boron trifluoride etherate $(67 \mathrm{mg}, 0.47 \mathrm{mmol})$ under a nitrogen atmosphere. The reaction solution was diluted with ether, and washed with $10 \%$ aqueous $\mathrm{HCl}$, saturated aqueous $\mathrm{NaHCO}_{3}$ and saturated aqueous $\mathrm{NaCl}$. The organic layers were combined, then dried over anhydrous $\mathrm{Na}_{2} \mathrm{SO}_{4}$ and concentrated in vacuo. The crude product was subjected to preparative TLC (ether-hexane, $1: 1)$ to give $(S)-(-)-8\left(158 \mathrm{mg}, 96 \%\right.$ yield, $[\alpha]_{\mathrm{D}}^{20}$ $-103.6^{\circ}\left(c=2.7\right.$, acetone), $96 \%$ ee). IR $v_{\max }^{\text {film }} \mathrm{cm}^{-1}: 1740(\mathrm{C}=\mathrm{O}), 1680$ $(\mathrm{C}=\mathrm{C}), 1600$ (aromatic), 1140 (sulfinate). ${ }^{1} \mathrm{H}-\mathrm{NMR}\left(\mathrm{CDCl}_{3}\right) \delta: 1.70$ $\left(3 \mathrm{H}, \mathrm{s}, \mathrm{CH}_{3} \mathrm{C}=\right), 1.80\left(3 \mathrm{H}, \mathrm{s}, \mathrm{C}_{3} \mathrm{C}\left(\mathrm{CH}_{2}\right)=\mathrm{CHOH}\right), 1.50-2.40(4 \mathrm{H}$, $\left.\mathrm{m},\left(\mathrm{CH}_{2}\right)_{2}\right), 2.10\left(3 \mathrm{H}, \mathrm{s}, \mathrm{CH}_{3} \mathrm{CO}_{2}\right), 2.40\left(3 \mathrm{H}, \mathrm{s}, \mathrm{CH}_{3} \mathrm{C}_{6} \mathrm{H}_{4}\right), 3.70-4.20$ $\left(2 \mathrm{H}, \mathrm{m}, \mathrm{TolS}(\mathrm{O}) \mathrm{OCH}_{2}\right), 4.30\left(2 \mathrm{H}, \mathrm{s}, \mathrm{AcOCH}_{2}\right), 5.00-5.60(2 \mathrm{H}, \mathrm{m}, 2 \mathrm{C}=$ $\mathrm{CH}), 7.10-7.70\left(4 \mathrm{H}, \mathrm{m}, \mathrm{C}_{6} \mathrm{H}_{4}\right)$. MS $m / z: 350\left(\mathrm{M}^{+}\right)$. Exact mass determination: 350.1632 (Calcd for $\mathrm{C}_{19} \mathrm{H}_{26} \mathrm{O}_{4} \mathrm{~S}: 350.1552$ ).

8-Acetoxy-2,6-dimethyl-2(E),6(Z)-octadienyl $(S)$-( - )-p-Toluenesulfinate (10) The reaction of $(S)-(+)-7(100 \mathrm{mg}, 0.47 \mathrm{mmol})$ with $6(200$ $\mathrm{mg}, 0.94 \mathrm{mmol}$ ) was carried out in the same way as described above to give $10\left(134 \mathrm{mg}, 81 \%\right.$ yield, $[\alpha]_{\mathrm{D}}^{20}-89.1^{\circ}(c=2.7$, acetone $), 83 \%$ ee $)$. IR $v_{\max }^{\text {film }} \mathrm{cm}^{-1}: 1740(\mathrm{C}=\mathrm{O}), 1690(\mathrm{C}=\mathrm{C}), 1600$ (aromatic), 1140 (sulfinate). ${ }^{1} \mathrm{H}-\mathrm{NMR}\left(\mathrm{CDCl}_{3}\right) \delta: 1.55-1.85\left(6 \mathrm{H}, \mathrm{m}, 2 \mathrm{CH}_{3} \mathrm{C}=\right), 2.00(3 \mathrm{H}, \mathrm{s}$, $\left.\mathrm{CH}_{3} \mathrm{CO}_{2}\right), 2.05-2.25\left(4 \mathrm{H}, \mathrm{m},\left(\mathrm{CH}_{2}\right)_{2}\right), 2.40\left(3 \mathrm{H}, \mathrm{s}, \mathrm{CH}_{3} \mathrm{C}_{6} \mathrm{H}_{4}\right)$, $3.75-4.70\left(4 \mathrm{H}, \mathrm{m}, \mathrm{TolS}(\mathrm{O}) \mathrm{OCH}_{2}, \mathrm{AcOCH}_{2}\right), 5.10-5.65(2 \mathrm{H}, \mathrm{m}$, $2 \mathrm{C}=\mathrm{CH}), 7.10-7.75\left(4 \mathrm{H}, \mathrm{m}, \mathrm{C}_{6} \mathrm{H}_{4}\right) . \mathrm{MS} m / z: 350\left(\mathrm{M}^{+}\right)$. Exact mass determination: 350.1544 (Calcd for $\mathrm{C}_{19} \mathrm{H}_{26} \mathrm{O} \mathrm{O}_{4} \mathrm{~S}: 350.1552$ ).

$(R)$-( -)-8-Acetoxy-3,7-dimethyl-3-p-toluenesulfonyl-1,6(E)-octadiene (9) A solution of $(S)-(-)-8\left(100 \mathrm{mg}, 0.29 \mathrm{mmol},[\alpha]_{\mathrm{D}}^{20}-103.6^{\circ}(c=2.7\right.$, acetone), $96 \%$ ee) in anhydrous DMF $(2 \mathrm{ml})$ was stirred at $105^{\circ} \mathrm{C}$ for $8 \mathrm{~h}$ and then concentrated in vacuo. The crude product was subjected to preparative TLC (ether-hexane, 1:1) to give $(R)-(-)-9(95 \mathrm{mg}, 95 \%$ yield, $[\alpha]_{\mathrm{D}}^{20}-5.8^{\circ}(c=1.2$, acetone $), 38 \%$ ee $)$. IR $v_{\max }^{\text {film }} \mathrm{cm}^{-1}: 1740(\mathrm{C}=\mathrm{O})$, $1640(\mathrm{C}=\mathrm{C}), 1600$ (aromatic), 1300, 1140 (sulfone). ${ }^{1} \mathrm{H}-\mathrm{NMR}\left(\mathrm{CDCl}_{3}\right)$ $\delta: 1.70\left(3 \mathrm{H}, \mathrm{s}, \mathrm{CH}_{3} \mathrm{C}=\right), 1.80\left(3 \mathrm{H}, \mathrm{s},=\mathrm{C}\left(\mathrm{CH}_{3}\right) \mathrm{CH}_{2} \mathrm{OH}\right), 2.00(3 \mathrm{H}, \mathrm{s}$, $\left.\mathrm{CH}_{3} \mathrm{CO}_{2}\right), 2.10-2.50\left(4 \mathrm{H}, \mathrm{m},\left(\mathrm{CH}_{2}\right)_{2}\right), 2.40\left(3 \mathrm{H}, \mathrm{s}, \mathrm{CH}_{3} \mathrm{C}_{6} \mathrm{H}_{4}\right)$, $4.40-4.70\left(2 \mathrm{H}, \mathrm{m}, \mathrm{AcOCH}_{2}\right), 4.80-5.95\left(5 \mathrm{H}, \mathrm{m}, \mathrm{CH}=\mathrm{CH}, \mathrm{CH}_{2}=\mathrm{CH}\right)$, $7.30-8.00\left(4 \mathrm{H}, \mathrm{m}, \mathrm{C}_{6} \mathrm{H}_{4}\right)$. MS $m / z: 350\left(\mathrm{M}^{+}\right)$. Exact mass determination: 350.1874 (Calcd for $\mathrm{C}_{19} \mathrm{H}_{26} \mathrm{O}_{4} \mathrm{~S}: 350.1552$ ).

(S)-(-)-8-Acetoxy-2,6-dimethyl-3-p-toluenesulfonyl-1,6(Z)-octadiene (11) The thermal rearrangement of $(S)-(-)-10\left([\alpha]_{\mathrm{D}}^{20}-89.1^{\circ}(c=2.7\right.$, acetone), $83 \%$ ee) was carried out in DMF at $100^{\circ} \mathrm{C}$ for $8 \mathrm{~h}$ and the same work-up as described above gave $(S)-(-)-11\left(95 \%\right.$ yield, $[\alpha]_{\mathrm{D}}^{20}$ $-6.1^{\circ}(c=2.2$, acetone $), 37 \%$ ee). IR $v_{\max }^{\text {film }} \mathrm{cm}^{-1}: 1740(\mathrm{C}=\mathrm{O}), 1640$ $(\mathrm{C}=\mathrm{C}), 1600$ (aromatic), 1300, 1140 (sulfone). ${ }^{1} \mathrm{H}-\mathrm{NMR}\left(\mathrm{CDCl}_{3}\right) \delta$ : $1.50-2.25\left(4 \mathrm{H}, \mathrm{m},\left(\mathrm{CH}_{2}\right)_{2}\right), 1.70\left(3 \mathrm{H}, \mathrm{s}, \mathrm{CH}_{3} \mathrm{C}=\right), 1.80(3 \mathrm{H}, \mathrm{s}$,
$\left.=\mathrm{C}\left(\mathrm{CH}_{3}\right) \mathrm{CH}_{2} \mathrm{OH}\right), 2.00\left(3 \mathrm{H}, \mathrm{s}, \mathrm{CH}_{3} \mathrm{CO}_{2}\right), 2.40\left(3 \mathrm{H}, \mathrm{s}, \mathrm{CH}_{3} \mathrm{C}_{6} \mathrm{H}_{4}\right), 4.35$ $\left(2 \mathrm{H}, \mathrm{d}, J=7 \mathrm{~Hz}, \mathrm{AcOCH}_{2}\right), 5.10-5.95\left(5 \mathrm{H}, \mathrm{m}, \mathrm{CH}=\mathrm{CH}, \mathrm{CH}_{2}=\mathrm{CH}\right)$, 7.05-7.80 (4H, m, $\left.\mathrm{C}_{6} \mathrm{H}_{4}\right)$. MS $m / z: 350\left(\mathrm{M}^{+}\right)$. Exact mass determination: 350.1371 (Calcd for $\mathrm{C}_{19} \mathrm{H}_{26} \mathrm{O}_{4} \mathrm{~S}: 350.1552$ ).

$(1 R, 3 S)$-3-Isopropenyl-1-methyl-2-methylene-1-p-toluenesulfonylcyclopentane (14a) A mixture of bis(dibenzylideneacetone)palladium $\left[\mathrm{Pd}(\mathrm{dba})_{2}\right](4.1 \mathrm{mg}, 0.007 \mathrm{mmol})$ and $\mathrm{PPh}_{3}(5.6 \mathrm{mg}, 0.021 \mathrm{mmol})$ in anhydrous $\mathrm{AcOH}(1 \mathrm{ml})$ was stirred at room temperature for $5 \mathrm{~min}$ under a nitrogen atmosphere. A solution of $(R)-(-)-9(50 \mathrm{mg}, 0.14 \mathrm{mmol})$ in anhydrous $\mathrm{AcOH}(1 \mathrm{ml})$ was added and the reaction mixture was stirred at $80^{\circ} \mathrm{C}$ for $4 \mathrm{~h}$. The mixture was filtered through Celite and the filtrate was concentrated to dryness under reduced pressure. The residue was diluted with dichloromethane, and the solution was washed with saturated aqueous $\mathrm{NaHCO}_{3}$ and saturated aqueous $\mathrm{NaCl}$. The organic layers were combined, dried over anhydrous $\mathrm{Na}_{2} \mathrm{SO}_{4}$, and concentrated in vacuo. The crude product was subjected to preparative TLC (etherhexane, $1: 2)$ to give $(1 R, 3 S)$-14a $(13 \mathrm{mg}, 31 \%$ yield). The results with $( \pm)-9$ and $(R)-(-)-9$ obtained under other reaction conditions are

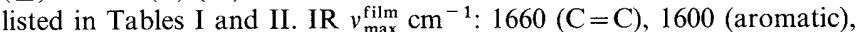
1300,1140 (sulfone). ${ }^{1} \mathrm{H}-\mathrm{NMR}\left(\mathrm{CDCl}_{3}\right) \delta: 1.55\left(3 \mathrm{H}, \mathrm{s}, \mathrm{CH}_{3} \mathrm{CSO}_{2} \mathrm{Tol}\right)$, $1.70\left(3 \mathrm{H}, \mathrm{s}, \mathrm{CH}_{3} \mathrm{C}=\right), 2.40\left(3 \mathrm{H}, \mathrm{s}, \mathrm{C}_{3} \mathrm{C}_{6} \mathrm{H}_{4}\right), 1.60-2.70(5 \mathrm{H}, \mathrm{m}$, $\left.\mathrm{CH}_{2}=\mathrm{C}\left(\mathrm{CH}_{3}\right) \mathrm{CH},\left(\mathrm{CH}_{2}\right)_{2}\right), 4.80,4.90\left(2 \mathrm{H}, \mathrm{ss}, \mathrm{CH}_{2}=\mathrm{C}\right), 5.10-5.30$ $\left(2 \mathrm{H}, \mathrm{dd}, \mathrm{CH}_{2}=\mathrm{C}\right), 7.25-7.80\left(4 \mathrm{H}, \mathrm{dd}, \mathrm{C}_{6} \mathrm{H}_{4}\right)$. MS $m / z: 290\left(\mathrm{M}^{+}\right)$. Exact mass determination: 290.1339 (Calcd for $\mathrm{C}_{17} \mathrm{H}_{22} \mathrm{O}_{2} \mathrm{~S}: 290.1028$ ).

\section{References}

1) W. Oppolzer, Angew. Chem., Int. Ed. Engl., 16, 10 (1977); A. G. Fallis, Can. J. Chem., 62, 183 (1984); M.-C. Lasne, J.-L. Ripoll, Synthesis, 1985, 121; R. S. Schmidt, Acc. Chem. Res., 19, 250 (1986); W. H. Okamura, M. L. Curtin, Synlett, 1990, 1.

2) a) H. M. R. Hoffmann, Angew. Chem., Int. Ed. Engl., 8, 556 (1969); b) W. Oppolzer, V. Sniekus, Angew. Chem., 90, 506 (1978); c) B. B. Snider, Acc. Chem. Res., 13, 426 (1980); d) W. Oppolzer, Angew. Chem., Int. Ed. Engl., 28, 38 (1989).

3) W. Oppolzer, Angew. Chem., Int. Ed. Engl., 23, 876 (1984).

4) W. Oppolzer, Pure Appl. Chem., 60, 39 (1988); B. M. Trost, Angew. Chem., Int. Ed. Engl., 28, 1173 (1989).

5) W. Oppolzer, J.-M. Gaudin, Helv. Chim. Acta, 70, 1477 (1987); W. Oppolzer, Chimia, 42, 212 (1988); W. Oppolzer, J.-M. Gaudin, M. Bedoya-Zurita, J. Hueso-Rodriguez, T. M. Raynham, C. Rodyr, Tetrahedron Lett., 29, 4709 (1988); W. Oppolzer, R. E. Swenson, J.-M. Gaudin, ibid., 29, 5529 (1988); W. Oppolzer, M. BedoyaZurita, C. Y. Switzer, ibid., 29, 6433 (1988); W. Oppolzer, T. H. Keller, M. Bedoya-Zurita, C. Stone, ibid., 30, 5883 (1989); W. Oppolzer, R.E. Swenson, W. Pachinger, Helv. Chim. Acta, 72, 14 (1989); W. Oppolzer, T. H. Keller, D. L. Kuo, W. Pachinger, Tetrahedron Lett., 31, 1265 (1990); B. M. Trost, J. I. Luengo, J. Am. Chem. Soc., 110, 8239 (1988); E. Negishi, S. Iyer, C. J. Rousset, Tetrahedron Lett., 30, 291 (1989); K. Yamamoto, M. Terakado, K. Murai, M. Miyazawa, J. Tsuji, K. Takahashi, K. Mikami, Chem. Lett., 1989, 955.

6) K. Hiroi, Y. Kurihara, J. Chem. Soc., Chem. Commun., 1989, 1778; K. Hiroi, K. Hirasawa, Chem. Pharm. Bull., 42, 786 (1994).

7) W. Oppolzer, J.-M. Gaudin, T. N. Birkinshaw, Tetrahedron Lett., 29, 4705 (1988); W. Oppolzer, T. N. Birkinshaw, G. Bernadinelli, ibid., 31, 6995 (1990).

8) a) K. Hiroi, R. Kitayama, S. Sato, J. Chem. Soc., Chem. Commun., 1983, 1470; idem, Chem. Pharm. Bull., 32, 2628 (1984); idem, J. Chem. Soc., Chem. Commun., 1984, 303; idem, Chem. Lett., 1984, 929; b) K. Hiroi, Yuki Gosei Kagaku Kyokai Shi, 44, 907 (1986); c) K. Hiroi, K. Makino, Chem. Lett., 1986, 617; idem, Chem. Pharm. Bull., 36, 1744 (1988).

9) U. T. Bhalerao, H. Rapoport, J. Am. Chem. Soc., 93, 4835 (1971); M. A. Umbriet, K. B. Sharpless, ibid., 99, 5526 (1977).

10) K. K. Anderson, W. Gaffield, N. E. Papanikolau, J. W. Foley, R. I. Perkins, J. Am. Chem. Soc., 86, 5637 (1964). 